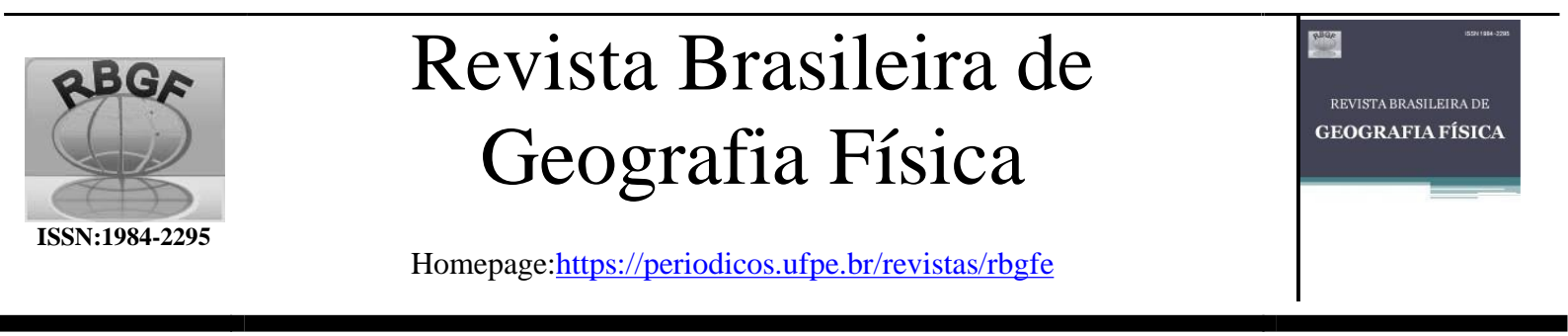

\title{
Geomorphology, morphometry and evidence of tectonics in the Araçaji Chart, Eastern Edge of Paraíba
}

\author{
Max Furrier, e-mail: max_furrier@hotmail.com (Autor Correspondente). Departamento de \\ Geociências/Universidade Federal da Paraíba. Ivanildo Costa da Silva. Departamento de \\ Geografia/Universidade Estadual da Paraíba
}

Artigo recebido em 05/12/2019 e aceito em 13/06/2020

\begin{abstract}
A B S T R A C T
The present article has as objective to analyse the interrelations between the relief, the lithology, the hydrography and the conspicuous evidence of tectonics on the area covered by the Araçaji 1: 25.000 chart, State of Paraíba, Northeast Brazil. The results showed the existence of anomalies in the study a rea, such as altimetry with disproportionate dimensions to the regional average, strong channel inflections, rectilinear channels and modified patterns in the drainage network influenced mainly by the local geological framework and possibly the Cenozoic tectonics. Allied to this qualitative analysis, morphometric indices were applied, for which the values obtained corroborate the tectonic influence in the area. The methodology used in this article requires a greater comparison to results obtained in other areas of the Atlantic continentalborder.
\end{abstract}

Keywords: Structural Geomorphology; Watershed; Mamanguape River; Draina ge network.

\section{Geomorfologia, morfometria e evidências de tectônica na Folha Araçaji, Borda Oriental da Paraíba}

\section{R E S U M O}

O presente artigo tem como objetivo analisar as interrelações existentes entre o relevo, a litologia, a hidrografia e a conspícua evidência tectônica da área da folha Araçaji na escala de 1:25.000, Estado da Paraíba, Nordeste do Brasil. Os resulta dos mostraram a existência de a nomalia s na área em questão, como altimetria com cotas desproporcionais à média da região, fortes inflexões na direção de canais, canais retilíneos e padrões modificados na rede de drenagem influenciados, principalmente, pelo arcabouço geológico local e, possivelmente, pela tectônica cenozoica. Aliados a essa análise qualitativa, foram aplicados índices morfométricos, nos quais os valores obtidos corroboram com a influência tectônica na área. A metodologia emprega da neste artigo carece de maior comparação com resultados obtidos em outras áreas da borda continental atlântica.

Palavras-chave: Geomorfologia Estrutural; Bacia Hidrográfica; Rio Mamanguape; Rede de drenagem.

\section{Introduction}

This article addresses the mutual relations of lithology, hydrography and tectonics in the configuration of relief in the Araçaji topographic chart, eastern border of the State of Paraíba. This topographic chart has a scale of 1:25,000 and equidistance of the $10 \mathrm{~m}$ contour lines. It was elaborated by the Superintendência de Desenvolvimento do Nordeste (SUDENE) in 1974, through triangulation aerophotogrammetry and technical support on the ground, which gives it high precision, much higher than the images of the Shuttle Radar Topography Mission (SRTM) with resolution of $30 \mathrm{~m}$.
This chart provides several attributes necessary for accurate morphological and morphometric analysis, such as contour lines with $10 \mathrm{~m}$ equidistance, rated points and a very detailed hydrographic network. The choice of the referred topographic chart is due to the fact that it is an integral part of the regional project of geomorphological mapping of the eastern border of the State of Paraíba, developed by the Laboratory of Geological and Environmental Studies of the Federal University of Paraíba.

Morphometric analyzes are being investigated in the watersheds of the Guadu, Itapororoca, Seco and Araçaji rivers, all tributaries of the Mamanguape River that crosses the chart 
from west to east in addition to being the main river on the north coast of the State of Paraíba and being confined, in its medium and low course, in a Cenozoic graben (Furrier, Nóbrega and Souza, 2014).

Rodrigues and Adami (2009) affirm that these charts are very important for data collection for further morphometric analysis. Although the vectorization of your data is an arduous and expensive task, the resulting precision proved to be quite satisfactory.

In Brazil, doctoral theses by Bezerra (1998), Furrier (2007), Barbosa (2017) and Silva (2020), in addition to several published articles, suggest that the tectonic stability of the Brazilian Continental Margin is only relative, and that this tectonic cannot be neglected more in geomorphological works, mainly those of a morphostructural nature.

In the past, geomorphological studies on the coastal rear of Northeast Brazil were strongly based on processes of climatic planing. This research tries to demonstrate that there is a tectonic factor that cannot be neglected and must be addressed with other technical and methodological biases.

The current challenges are to try to measure this tectonics through data obtained in the thematic maps generated and the use of morphometric calculations in the drainage network to, in this way, obtain relative dates regarding the movements and the derived morphologies and, mainly, confront data obtained in other regions of Brazil and other countries bordering the Atlantic Ocean.

\section{Geological and structural characterization}

The study area is located in the Geotectonic Province of Borborema (Figure. 1), east of the Borborema Plateau, more precisely in the morphological region called the Superficie PreLitorânea (SPL), defined and delimited by Costa et al. (2020). This flattened surface is located between the eastern edge of the Borborema Plateau and the Coastal Tablelands sculped on the Barreiras Formation, in the State of Paraíba.

Its division into tectono-stratigraphic terrains comes from the Brasiliana orogenesis that affected the entire Borborema Province until the beginning of the Ordovician $(\sim 490 \mathrm{Ma})$, indistinctly marking all of its terrains with a strong system of flowing shear zones and remarkable granitic plutonism. In the domains of this province, rocks of Archean ages can be found, but rocks with Paleo to Mesoproterozoic ages predominate, which are grouped in the northern, transversal and meridional sub-provinces, separated by the Patos and Pernambuco lineaments that have E - W direction (Brito Neves et al., 2008).

Much of the Province of Borborema, including the area covered by the Superficie PréLitorânea (SPL), would be formed by reworking the Paleoproterozoic crust during the Brasilian cycle. These structures, after reaching their tectonic stability, underwent new tensions during the last major tectonic event that took place in South America and West Africa, which was the separation of these continents in Mesozoic (Bezerra et al., 2001). In recent studies, Maia and Bezerra (2020) stated that these reactivations of Precambrian fault zones, caused by the continuous movement of South America towards the west, caused deformations in sedimentary deposits of Neogene to Quaternary. 


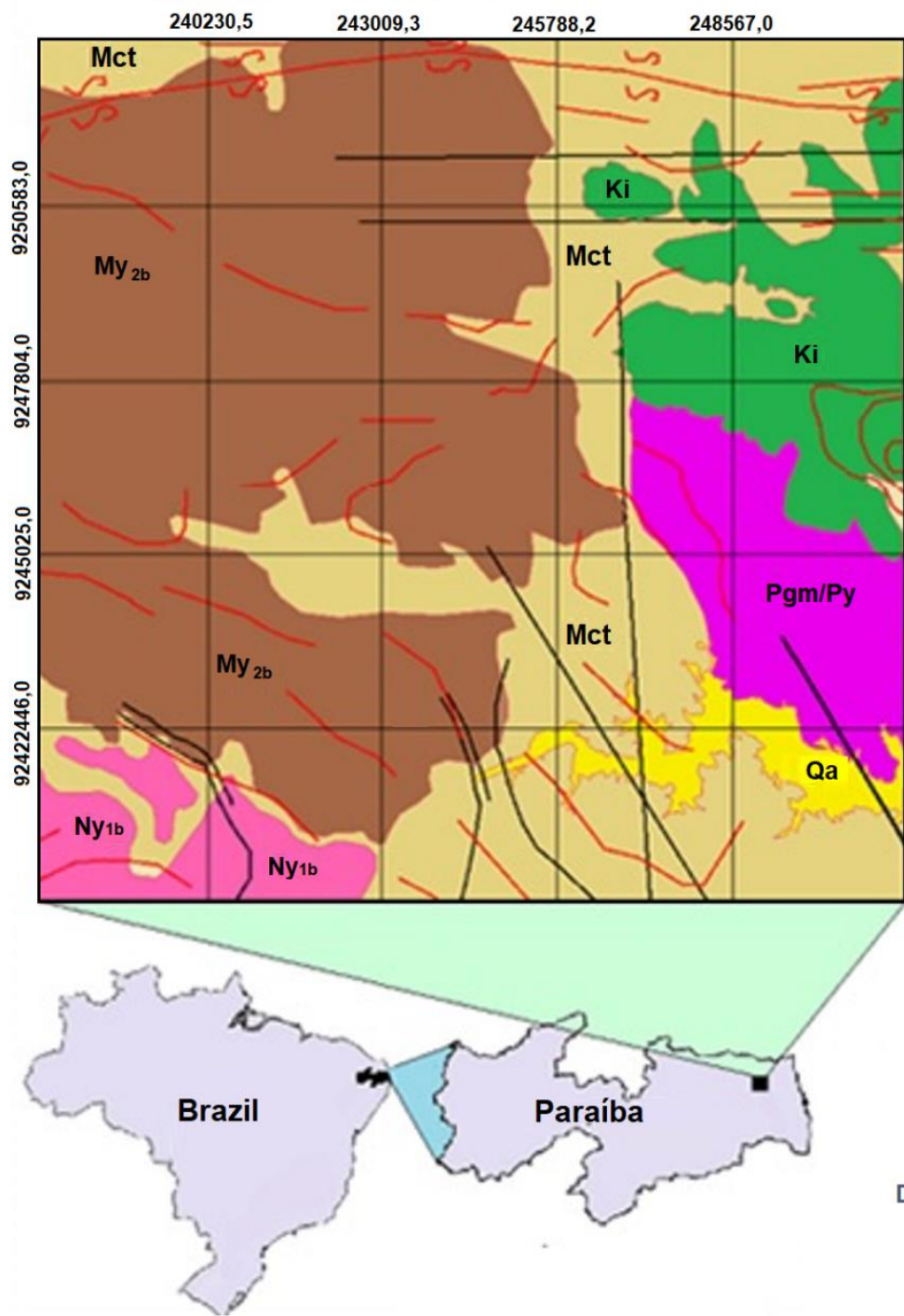

\section{Geological Units}

Alluvion

Volcanic Felsic Itapororoca (Ki?)

Granitic Suite: granites and granodiorites associated with

São Caetano Complex: muscovitebiotite gneiss, biotite-gneiss and muscovite schist.

Gneissic-Migmatitic

Complex: orthogneiss of granitic and dioritic composition, migmatites and pegmatites. and migmatite.

Figure 1. General geology and location of the study area (Source: Adapted from Sudene (1974); modified by Santos, Ferreira and Silva Júnior (2002) and Brito Neves et al., (2008).

Several studies point to indications of fault reactivations in the geological context where the Araçaji 1: 25,000 chart and its surroundings are inserted, including in the Patos Lineament and in the Mamanguape River Graben (Furrier; Araújo; Meneses, 2006; Mantovani et al., 2008; Brito Neves et al., 2008; Silva, 2020). Such reactivations would have affected rocks belonging to crystalline basement, which, in turn, affected rocks generated and deposited in relatively recent periods, ranging from the Cretaceous to the Neogene.

With the continuous separation of the South American Plate from the African Plate, there is a continuous adjustment of the lithology of the entire area, which is substantially reflected in the arrangement and morphology of the drainage network, showing patterns incompatible with a classic hydrographic evolution proclaimed in tectonically stable zones.

\section{Materials and methods}

The methodological structuring of this article is based on two investigative lines: a qualitative bias, which investigates the forms of relief and its interrelationships with hydrography and geology and a quantitative analysis, which studies the relationship between geomorphology/tectonics/hydrography through application of morphometric indices very widespread today.

Florenzano (2008) reports that in geomorphological studies the qualitative aspects refer to the descriptive analyzes of the relief, represented by its forms and appearance, such as, for example, flat, hill, mountainous etc. Qualitative aspects of the relief can also be understood as its spatial organization, genesis, chronology and explanation. Quantitative data refer to morphometry, represented by variables related to measures of height, length, width, surface, volume, 
inclination (slope), curvature, orientation, density and frequency of its forms.

The structural and tectonic character in understanding the configuration of the relief has been gaining scope in Brazil since the pioneering works of Pontes (1969) and Leite (1973), who observed abrupt altimetric unevenness delimiting parallel levels, suggestive of reactivation by faults in the Coastal Boards of the State of Sergipe due to the constant separation between South America and the African continent.

These more recent studies, such as Lima (2000) and Bezerra et al., (2001), for the Northeast coast; Hiruma et al., (2001), in the Southeast region; Costa et al., (1996), for the Amazon region, corroborate the structural and tectonic character in the configuration of the relief for several Brazilian geographic regions. Maia and Bezerra (2020) conspicuously demonstrate that much of the relief of the Northeast Region has a strong structural character in its configuration.

For Hartwig and Riccomini (2010), the morphometric analyses applied on reliefs with a strong structural character may allow the identification of anomalies in the relief pattern that may show recent tectonic movements, and which are not always visible on the surface. For the authors, in general, these analyses precede the fieldwork and aim at the preliminary identification of areas with a higher probability of structuraltectonic occurrences.

Marques (2012) states that it was the work of R. E. Horton and A. N. Strahler towards morphometry that opened new horizons for geomorphology, allowing to obtain results based on the attribution of numerical values regarding the ordering of river channels.

In Brazil, since the 1980s, several studies have used morphometric parameters to analyze the relief and its interrelationships with hydrography and geology, the most used being the StreamGradient Index (SL) (Etchebehere et al., 2004; Passarella et al., 2016; Andrades Filho and Rossetti, 2018). For Passarella et al. (2016), the morphometric parameters of the relief are essential for the characterization and understanding of the formation of a landscape, especially in regions where the erosive and tectonic processes are well marked in the relief, a very noticeable situation in the region where the present study was developed.

In the present study, much attention was paid to what Andrades Filho and Rossetti (2018) warn, because, for the aforementioned author, the application of morphometric indices requires a careful analysis, since the relief forms can present morphometric results, that indicate recent tectonic activity, but that are related to structures elaborated and maintained in prominence by the lithological resistance or by actions of past and current climatic processes.

In addition to the Brazilian studies previously presented, several authors of international works attest to the validity of the application of morphometric indices in interrelated studies of relief and hydrography. Among them we can mention the works of Jordan (2003), in Hungary; Kaur et al. (2014) and Kulkarni (2015), in India; Furrier and Cuervo (2018), in the region of Cartagena de Indias, Colombia and Ivanov and Yermolaev (2018), in Russia.

It is worth noting that works of a structural and tectonic nature are being developed in Portugal and realizing that the morphology of the relief of several regions of this country is under strong influence of the lithological structure and the tectonic structure. These works are being carried out by geologists and geographers, such as Barbosa (1995), Martins (1999) and Martins et al. (2009) in the Tagus Basin; Dias (2001), for the Algarve region and Teixeira (2006) for the Center-North of the country.

The fieldwork, as well as the previous analysis of satellite images and, mainly, of the topographic map, are essential in the qualitative investigation, since they can reveal morphostructural and morphotectonic performance in the general configuration of the relief and in the morphology of the hydrographic network as sudden inflections, channel straightness, asymmetric and centrifugal or centripetal drainages (Howard, 1967; Lima 2000; Peulvast and Claudino-Sales, 2002; Martinez, 2005; Furrier, 2007).

Leopold and Maddock Jr. (1953) corroborate the importance of applying quantitative analysis when they state that the qualitative approach to geomorphology has really been constructive, but it would be desirable to analyze some of the concepts quantitatively. Hack (1973), in this context, states that drainage networks have regular geometric properties and can also be described quantitatively. In the present study, the indices used for quantitative analysis were: a) Stream Gradient Index (SL), b) Valley Floor Width-Valley Height Ratio (Vf) and c) Asymmetric Factor (AF).

For Etchebehere et al. (2016), the SL can be applied to the entire length of the main river (SLtotal or SLt), which allows, for example, a regional assessment of large areas. Another way of using the SL concerns the analysis of drainage segments (SLsection or SLs), which has a more local relationship, applying to the analysis of possible detail tectonic deformation in drainage 
segments. These sections can be chosen using morphological parameters of an anomalous section of the channel, such as a sudden inflection, for example. The calculation of SLt or SLs can be done through the mathematical expressions exposed inside figure 2 .

In the formulaspresented to obtain the SLt, $\Delta \mathrm{h}$ is the altimetric difference between two extreme points of a section along the watercourse, $\ln$ corresponds to the natural logarithm of the total length of the river and $\mathrm{L}$ is the distance between the extreme points of the channel considering the sinuosity of the river. The anomalous segments detected in the application of the SL index would be out of this evolutionary balance, being considered knickpoints.
Similarly, for SLs, $\Delta \mathrm{h}$ is the altimetric difference between two points in the channel on which the index is being calculated, $\Delta l$ is the length in horizontal projection of the highlighted section and $\mathrm{L}$ is the total length of the watercourse, upstream the midpoint of the section for which the index is being calculated.

This was the principle applied by Volkov et al. (1967), who studied the Russian platform seeking to detect crustal movements by applying mathematical equations from the parables that best fit the longitudinal profiles of the rivers. The anomalous stretches represented curve segments with greater distance, positive or negative, in relation to the longitudinal profile of each watercourse.

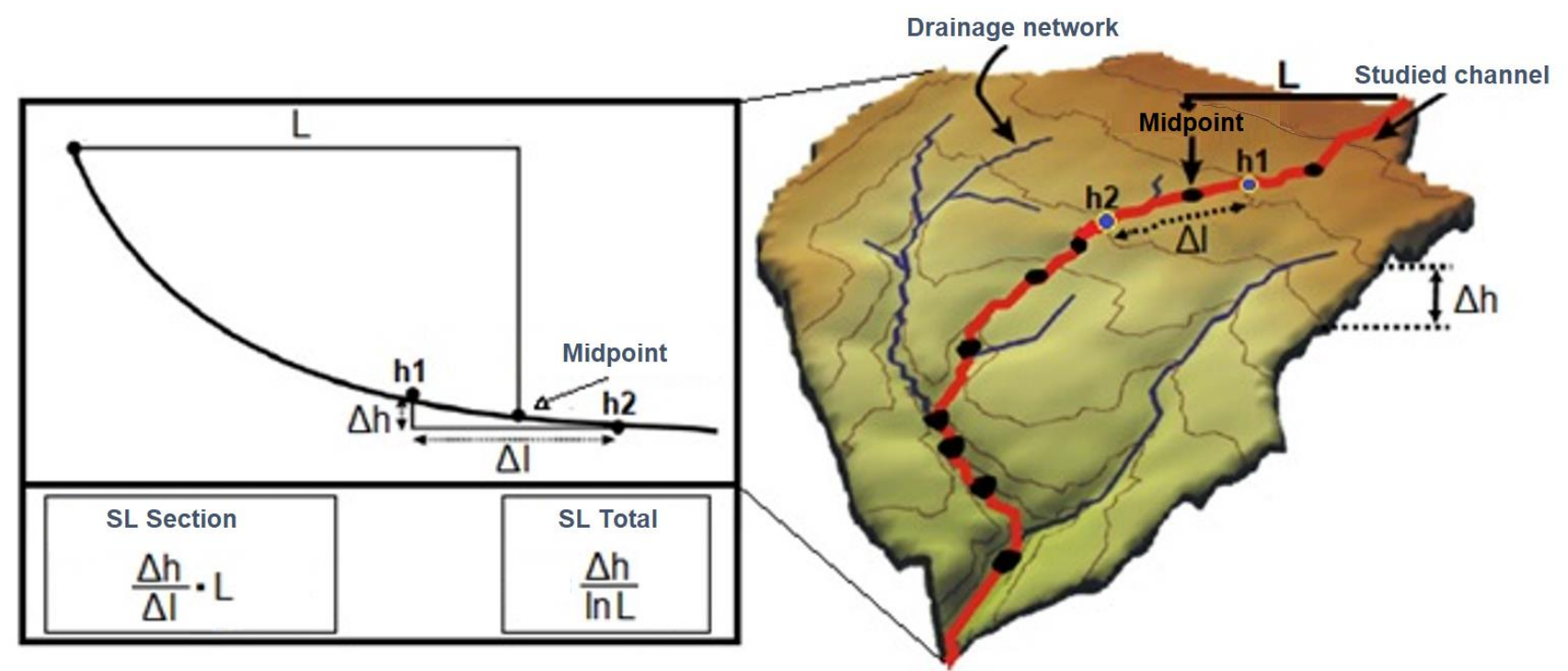

Figure 2. Parameters for calculating the Stream Gradient Index (SL)

Note: Points h1 and h2 represent two subsequent altimetric isolines (adapted from Font and Lagarde, 2010).

For Andrades Filho (2010), this index indicates significant changes in the declivity of the river channel, which can be associated with tributary outlets, different resistance to hydraulic erosion of the rocky substrate and/or to tectonic activity. The value of SLs considered anomalous will be that which, divided by SLt, obtains a value equal to or greater than 2 (Martinez, 2005). There are also two categories of anomalies: $2^{\text {nd }}$ order, with SL values equal to or greater than 2 and less than 10; and $1^{\text {st }}$ order anomalies, with values equal to or greater than 10 (Sebeer; Gornitz, 1983).
According to Bull and McFadden (1977), the $\mathrm{Vf}$ ratio indicates whether the water flow is rapidly eroding the valley as a result of some modification of the base level resulting from tectonic activity, or if lateral erosion of the channel slopes is occurring, indicating thus, tectonic stability. El Hamdouni et al. (2008) also state that low Vf values indicate incision processes, which are commonly associated with tectonic uplifts. The following equation shows how to calculate this index (Figure. 3). 


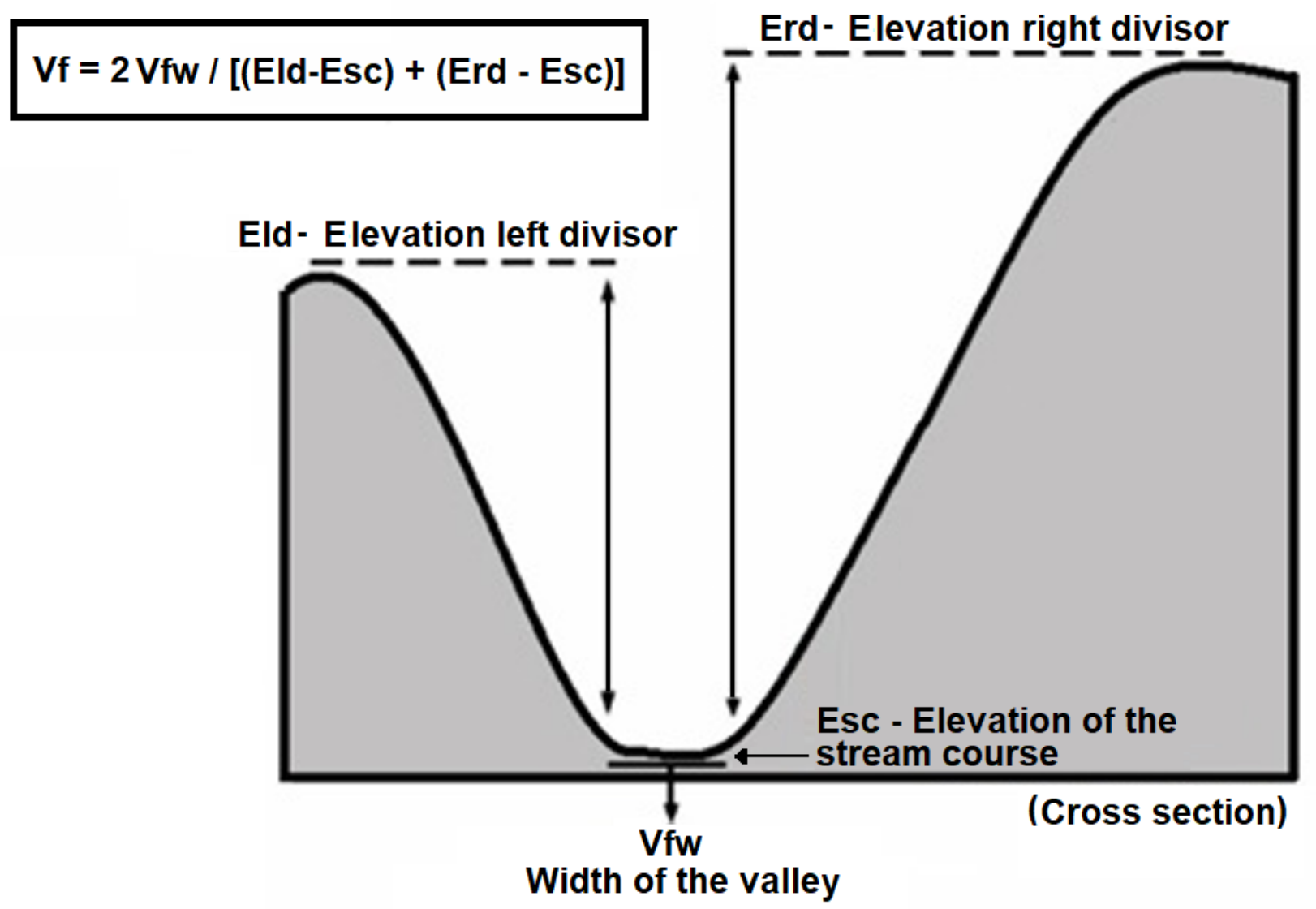

Figure 3. Mathematical formula and measurement procedures to obtain the values of the Vf ratio (Bull and McFadden, 1977).

For Bull and McFadden (1977), the element $\mathrm{Vf}$ represents the ratio between the width of the bottom and the elevation of the valley. $\mathrm{Vfw}$ is the width of the valley floor; Eld is the altimetric difference between the height of the water left divider and the height of the valley floor of the interfluvial line in the left portion of the valley; Erd corresponds to the elevation in the interflow line of the right portion of the valley; and Esc is the value of the average elevation of the valley floor.

For Silva et al. (2003), in general, the Vf values considered as indicators of uplift and, consequently, of recent tectonic activity, are low $(<1.0-V$-shaped valleys), while the values that indicate tectonic stability are higher $(>1.0-\mathrm{U}$ - shaped valleys). The authors also affirm that, as the Vf values vary, depending on the size of the watershed, the flow discharge and the type of rock, they must be obtained in places with similar geological characteristics, with the same lithological resistance to the denudational processes.

According to Souza and Rosseti (2011), the AF is primarily based on the measure of asymmetry, defined by the ratio of the areas occupied by the right and left banks of the main river. The Asymmetric Factor is defined by the equation $\mathrm{AF}=100(\mathrm{Ra} / \mathrm{Ta})$. Figure 4 illustrates how a tectonic tipping can affect the symmetry of a watershed. 

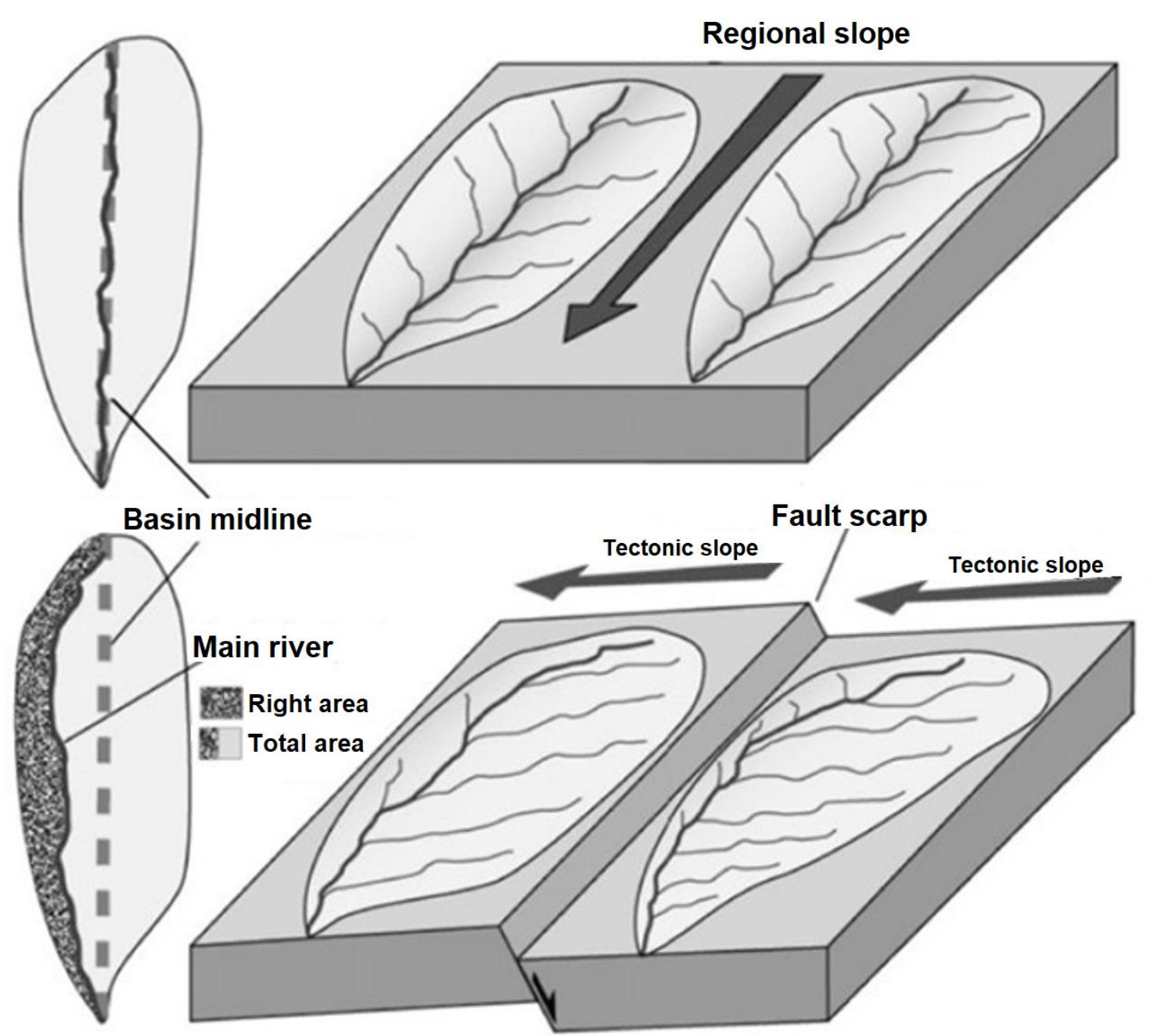

Figure 4. Drainage response to uplift a long a fault line (Mahmood \& Gloaguen, 2016).

The expression AF corresponds to the Asymmetric Factor, while Ra is the right sector of the watershed and Ta corresponds to the total area of the drainage basin. According to Ricón and Vegas (2000), the closer to 50 the values of the Asymmetric Factor obtained are, the smaller the possible influence of tectonic activity will be and vice versa. Therefore, a watershed with an $\mathrm{AF}=50$ would be a perfectly symmetrical watershed.

For Andrades Filho (2010), AF values much above or below 50 indicate, respectively, tipping on the right or left of the hydrographic watershed. This author also points out that watersheds with low asymmetry correspond to values of $\mathrm{AF}$ varying between $0-7$ of $\mathrm{AF}=50$, which would be a perfectly symmetrical watershed. For medium asymmetry, the values vary between 7 -15 of the $\mathrm{AF}=50$, and high asymmetry, where $\mathrm{AF}$ register values $<$ or $>15$. As an example, if a watershed has an $\mathrm{AF}=66$, that has a high asymmetry of 16 .

To analyze the geomorphology of the study area, a cartographic material was made up, composed substantially of the hypsometric and slope charts and the Digital Elevation Model (DEM). The thematic maps and the DEM were elaborated from data extracted from the topographic chart Araçaji 1: 25,000, through the values attributed to the contourlines and the quoted points.

The chart was digitized by means of a scanner and the following elements were vectored: contour lines with an equidistance of 10 meters; hydrography; rated points; road network and administrative limits. After digitization, vectorization and the preparation of cartographic materials was performed in the Spring 5.2 software.

It is worth noting that, due to the fact that several drainage channels in the study area, especially first-order channels, do not have their nomenclature presented on the Araçaji chart, numerical values were inserted to identify them. Such a procedure was necessary because it is necessary to mention a lot of these channels for the important roles they play in the configuration of the relief and for presenting, in some cases, significant anomalies in the network and drainage patterns. In 
addition, alphanumeric codes have been assigned to these channels to identify them. It is known that such identification is not usual, however, considering the interpretative value of this attribution, it was decided to proceed.

\section{Results and discussions}

\section{Qualitative analysis}

The highest altitudes of this chart occur at the Residual Level Itapororoca $(\sim 200 \mathrm{~m})$. It is an oblong structure inclined in the $\mathrm{E}-\mathrm{W}$ direction and strongly dissected in its $\mathrm{W}$ side by the Timbó stream. Such altimetric differentiation may be related to the lithological composition of this unit, formed, by Cretaceous felsic rocks with a high concentration of silica, which would provide greater resistance to erosive processes.

The hydrography verified in this sector is centrifugal, forming extremely tight valleys (Figure 5a). This geological structure is a remnant

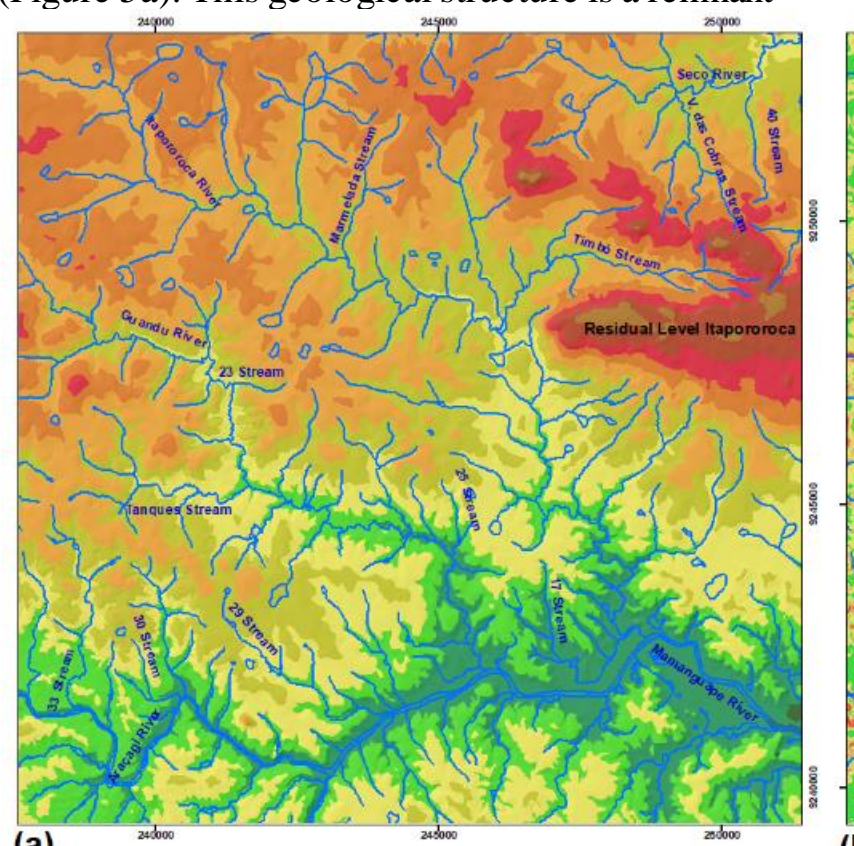

(a)

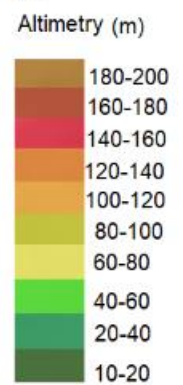

Area per $\mathrm{km}^{2}$

0,56
3,96
5,49
25,17
44,12
35,75
33,20
20,78
17,90
0,10

of the felsic phenomena of the opening of the Atlantic and, therefore, its lithology is totally different from the adjacent lithology in terms of age and composition. It is noticed in the relief sculpted in this geological structure, altitudes disproportionate to the average local elevation, sudden inflections in the adjacent river channels and very steep slopes that canbe seen in the clinical chart with slopes greater than $45 \%$ (Figure. 5b).

At Residual Level Itapororoca, the altitude reaches the maximum elevation of the chart $(198 \mathrm{~m})$, with the minimum elevation of this felsic structure being around $120 \mathrm{~m}$. The highest levels of slope (classes $20 \%$ to $75 \%$ ) are also seen in the relief developed over this lithology. Such characteristics put this unit in a prominent position in the topographic configuration and slope of the study area, since the altimetric predominance of the relief of the Araçaji chart area generally presents levels below 120 meters in areas composed of granitic and gneiss rocks of the Precambrian.

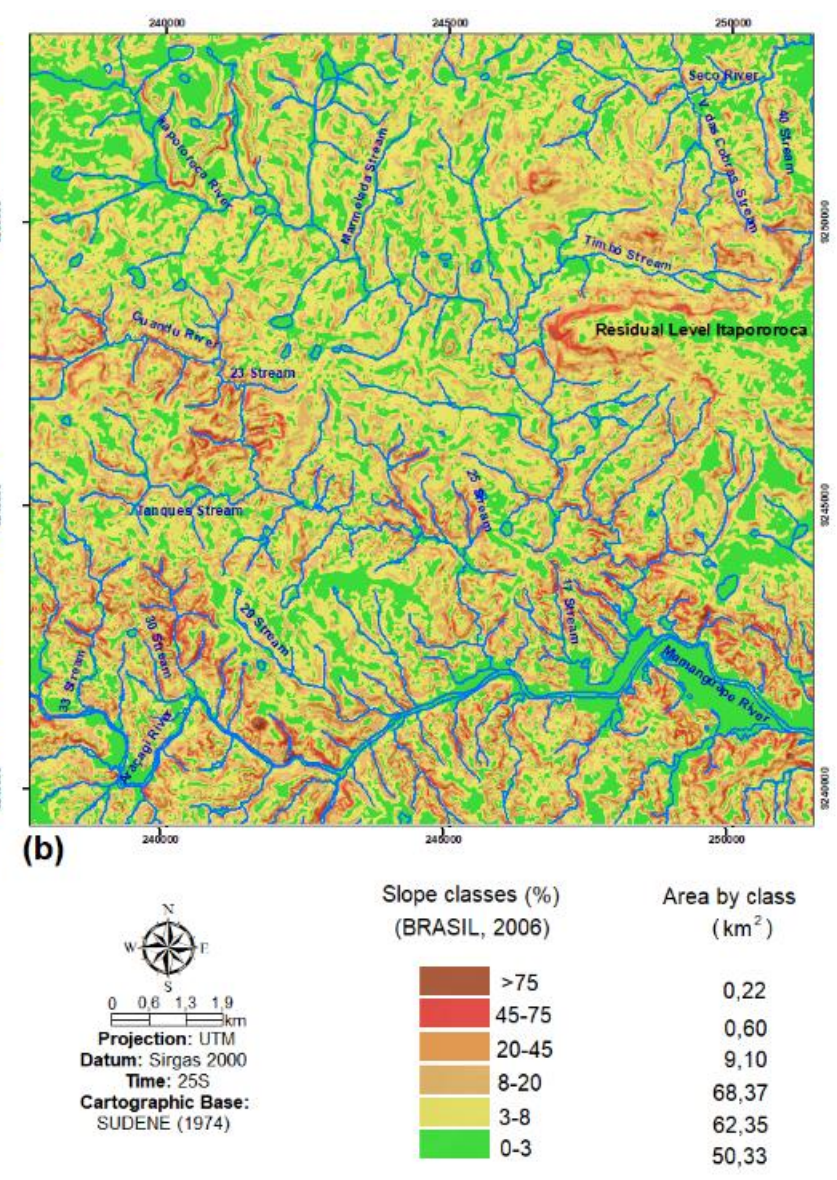

Figure 5. a) Altimetric chart of Araçaji; b) Slope chart of Araçaji.

The drainage network of the watershed in the study area, especially those of the Itapororoca and Guandu rivers, presents as the basic drainage pattern, the dendritic, however, in its configuration various signs of anomalies are observed that sometimes modify this pattern and give origin, for example, in centrifugal, annular, subparallel and sub-dendritic radial patterns, as occurs in the 
Tanques stream, west of the Araçaji chart (Figure 6).

In the Guandu River, the basic pattern seen is the dendritic (Figure 6) and the general direction of flow of this river is NW - SE. However, this channel suffers some sudden inflections, assuming $\mathrm{N}-\mathrm{S}$ directions between the confluence of stream
23 and the Tanques stream and, between the confluence of stream 25 with the mouth of the Guandu River, on the Mamanguape River. Structural formations of drainage patterns are also observed, such as a radial pattern, with annular and subparallel characteristics in the hydrography of the chart area (Figure 6).
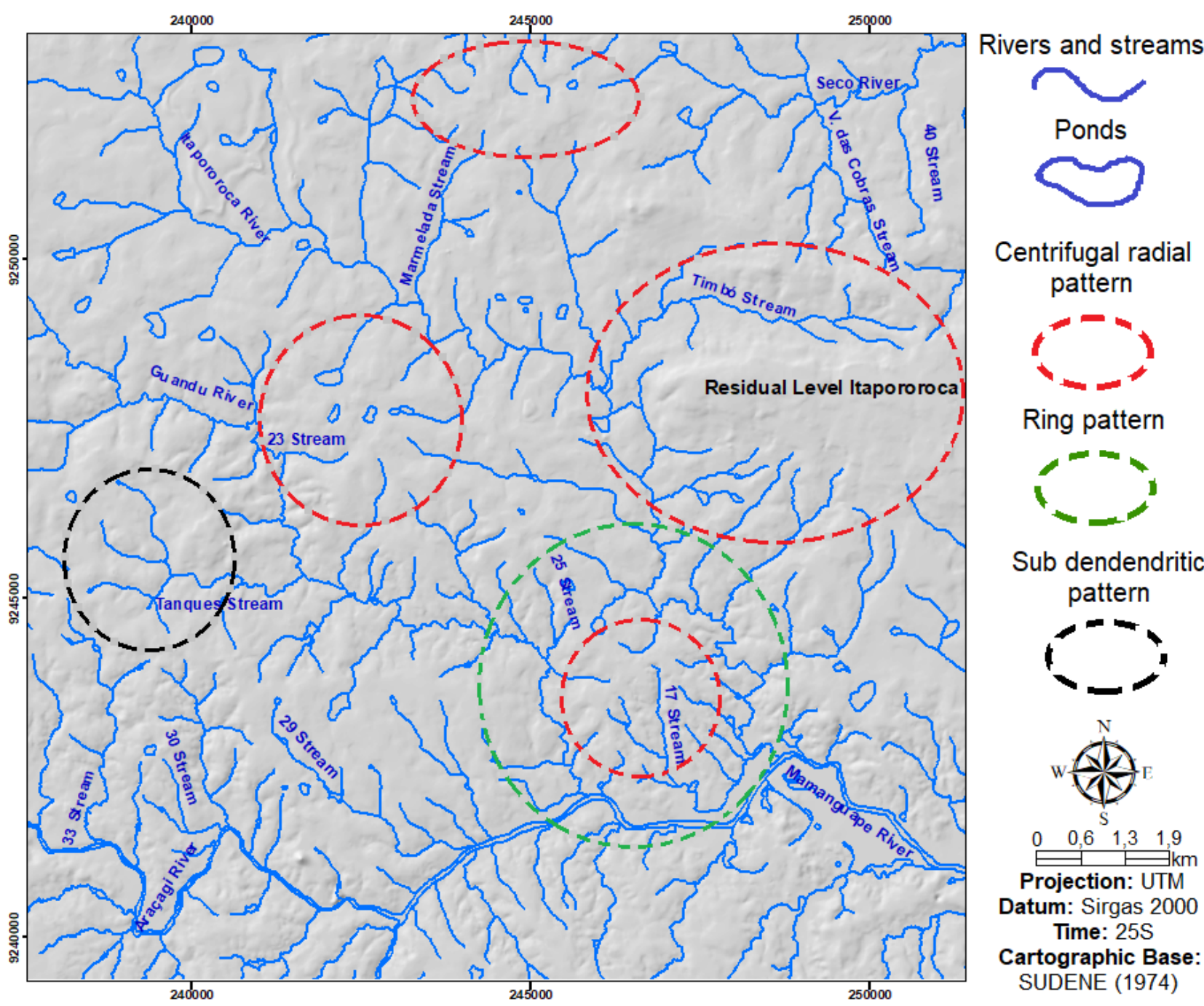

Centrifugal radial pattern

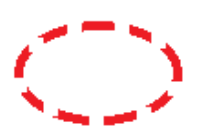

Ring pattern

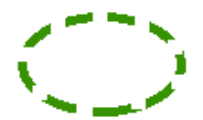

Sub dendendritic pattern
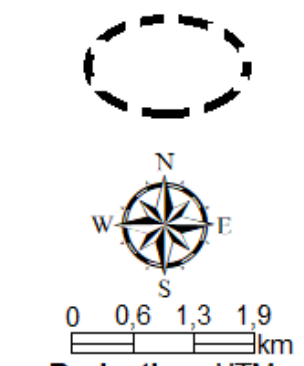

Projection: UTM

Datum: Sirgas 2000

Time: $25 \mathrm{~S}$

Cartographic Base:

SUDENE (1974)

Figure 6. Drainage patterns of the Araçaji chart 1: 25,000 with emphasis on the main anomalies presented in its configuration.

\section{Quantitative analyses}

\section{Stream Gradient Index (SL)}

Stream Gradient index was applied in streams 40, Marmelada, Timbó, 17, Tanques and in stream 33 (Fig.7). The results obtained with the SL, in its entirety, with the exception of segment 1 of stream 17 and segment 2 of stream Tanques, revealed values that correspond to second order anomalies.

In the Marmelada stream channel, which has uniform lithology, the results show that the two segments analyzed show values that correspond to channels that have a relevant tectonic influence. In segment 1, downstream, the SLs/SLt value of 3.75 was obtained; in segment 2 , upstream of the channel, this value was lower, at 2.65 , which represents a channel segment with less intensity, without large altimetric variations from tectonic movements or differentiated lithological resistance (Table 1). 


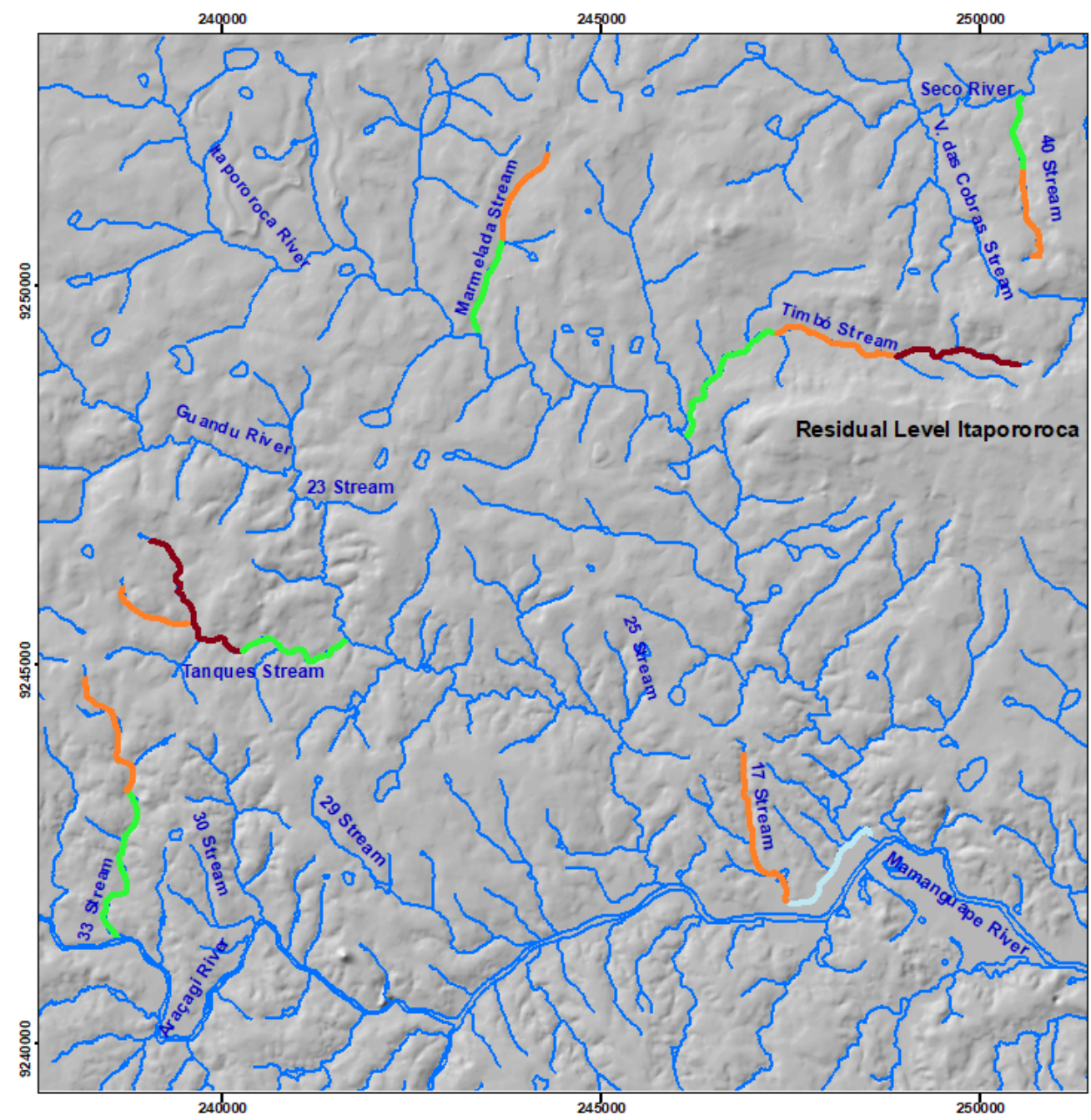

\section{Section with SL anomalies}

Section 1

Section 2

Section 3

Section without SL anomalies

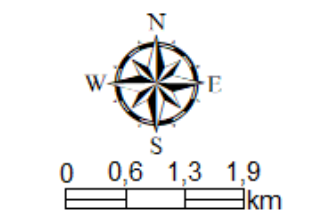

Projection: UTM

Datum: Sirgas 2000

Time: $25 \mathrm{~S}$

Cartographic Base:

SUDENE (1974)

Figure 7. Channels with segments selected for calculating the Stream Gradient index (SL).

In the Timbó stream (Figure 7), all analyzed segments showed values that correspond to anomalies. In its low course, the value obtained was 3.41. This segment is located on the metamorphic rocks of the São Caetano Complex. The second segment of the Timbó stream presented an intermediate value of SLs/SLt (2.42) and, when analyzing the geological map (Figure 1), it is observed that this segment is eroding two distinct geological units: the São Caetano Complex, in the its low course and the Itapororoca Volcanic Felsic unit in its high course. In addition to these characteristics, its direction is completely anomalous to the other courses with sense W.

In the segments studied in stream 17 , the existence of two distinct realities in the values of SLs/SLt were verified. In section 1, low course, which flows over Quaternary sediments deposited by the Mamanguape iver (Figure 1), the value obtained was 1.15 (Table 1). This value does not represent evidence of recent tectonic activity in the configuration of the longitudinal profile of the drainage channel. In section 2, the value of SLs obtained was the highest in the Araçaji chart (3.90). Although this sector is eroding two distinct geological units: the São Caetano Complex, upstream, and the alluviums, downstream, the value of SLs presented must be considered adequate, since this stretch is inserted in an area where several anomalies occur, such as channel inflections, dome formation, centrifugal radial drainage pattern and subparallel pattern (Figure 6). 
Revista Brasileira de Geografia Física v.13, n.04 (2020) 1570-1586.

Table 1. Values obtained with the application of the SL index in the studied watershed

\begin{tabular}{ccccccccc}
\hline $\begin{array}{c}\text { Main channel / } \\
\text { sections }\end{array}$ & $\begin{array}{c}\text { Upper } \\
\text { quote } \\
\mathbf{( m )}\end{array}$ & $\begin{array}{c}\text { Inferior } \\
\text { quote } \\
\mathbf{( m )}\end{array}$ & $\begin{array}{c}\text { Altimetric } \\
\text { difference } \\
\mathbf{( m )}\end{array}$ & $\begin{array}{c}\text { Total channel } \\
\text { length / } \\
\text { channel sections } \\
\mathbf{( m )}\end{array}$ & $\begin{array}{c}\text { Extension from } \\
\text { midpoint to } \\
\text { channel } \\
\text { upstream (m) }\end{array}$ & SLs & SLt & SLs/SLt \\
\hline Marmelada Stream & 120.1 & 90 & 30.1 & 2694 & - & - & 3.76 & - \\
\hline Marmelada (1) & $\mathbf{1 0 0}$ & $\mathbf{9 0}$ & $\mathbf{1 0}$ & $\mathbf{1 4 0 3}$ & $\mathbf{1 9 9 2}$ & $\mathbf{1 4 . 1}$ & $\mathbf{3 . 7 6}$ & $\mathbf{3 . 7 5}$ \\
\hline Marmelada (2) & 120 & 100 & 20 & 1291 & 645 & 9,99 & 3.76 & 2.65 \\
\hline Timbó Stream & 153.7 & 75.2 & 78.5 & 6238 & - & - & 8.99 & - \\
\hline Timbó (1) & 95 & 75 & 20 & 3060 & 4708 & 30.7 & 8.99 & 3.41 \\
\hline Timbó (2) & 110 & 95 & 15 & 1627 & 2365 & 21.8 & 8.99 & 2.42 \\
\hline Timbó (3) & 153.7 & 110 & 43 & 1551 & 775 & 21.4 & 8.99 & 2.38 \\
\hline 17 Stream & 60.2 & 24.8 & 35,4 & 4731 & - & - & 4.18 \\
\hline 17 (1) & 27.4 & 24.8 & 2.6 & 1997 & 3733 & 4.86. & 4.20 & 1.15 \\
\hline 17 (2) & $\mathbf{6 0 . 2}$ & $\mathbf{2 7 . 4}$ & $\mathbf{3 2 . 8}$ & $\mathbf{2 7 3 4}$ & $\mathbf{1 3 6 7}$ & $\mathbf{1 6 . 4}$ & $\mathbf{4 . 2 0}$ & $\mathbf{3 . 9 0}$ \\
\hline 40 Stream & 134.6 & 77.4 & 57.2 & 2646 & - & - & 7.25 \\
\hline 40 (1) & 90 & 77.4 & 12.6 & 1292 & 2000 & 19.5 & 7.25 & 2.68 \\
\hline 40 (2) & 134.6 & 90 & 44.6 & 1.353 & 676 & 22.8 & 7.25 & 3.14 \\
\hline Tanques Stream & 110.2 & 55.1 & 55.1 & 4663 & - & - & 6.20 \\
\hline Tanques (1) & $\mathbf{7 0 . 1}$ & $\mathbf{5 5 . 1}$ & $\mathbf{1 5}$ & $\mathbf{2 1 0 4}$ & $\mathbf{3 6 1 1}$ & $\mathbf{2 5 . 7}$ & $\mathbf{6 . 2 0}$ & $\mathbf{4 . 1 4}$ \\
\hline Tanques (2) & 104 & 80.3 & 23.7 & 1350 & 675 & 11.8 & 6.20 & 1,91 \\
\hline Tanques (3) & 110.2 & 70.1 & 40.1 & 2558 & 1279 & 20.5 & 6.20 & 3.23 \\
\hline 33 Stream & 110.2 & 40.2 & 70 & 5009 & - & - & 8.22 \\
\hline 33 (1) & $\mathbf{7 0 . 1}$ & $\mathbf{4 0 . 1}$ & $\mathbf{3 0}$ & $\mathbf{2 6 1 8}$ & $\mathbf{3 7 0 0}$ & $\mathbf{4 2 . 3}$ & $\mathbf{8 . 2 2}$ & $\mathbf{5 . 1 4}$ \\
\hline 33 (2) & 110.2 & 70.1 & 40.1 & 2391 & 1195 & 20.0 & 8.22 & 2.43 \\
\hline
\end{tabular}

Note: The values in bold represent the four channels with the most significant anomalies in SLs/SLt.

\section{Valley Floor Width-Valley Height Ratio (Vf)}

The Vf ratio was applied in the main channels of the watershed of the streams Marmelada, Timbó, Tanques and stream 30 and in the rivers Guandu, Itapororoca and Araçaji, in addition to a profile applied in a valley where no type of drainage is specified in the Araçaji chart, that was conventionally called in this work the Seco valley (Figure 8).

In the two profiles applied in the Timbo stream valley, profile 1 and profile 2, the lowest values of $\mathrm{Vf}$ in the Araçaji chart area were obtained, respectively, 0.56 and 0.36 . These Vf values, added to the qualitative characteristics and the results of the SLs index applied in the area of the Itapororoca Volcanic Felsic, reinforce the idea that this geological unit has evidence of recent tectonic activity. These indices found attest to a strong fluvial notch with accelerated headland retreat, that is, a morphometric result, corroborating with a morphological analysis.

In the channel of stream 30 and Guandu River, Vf values of 0.63 and 0.76 were obtained, respectively. The Vf value obtained in the Itapororoca River channel (0.57) should be interpreted with greater caution, because in the profile applied in this channel, the left and right margins are represented by different lithotypes. However, it is worth noting that the results presented in this location should not be discarded, since they were obtained in an area of the chart where the qualitative analysis and other indices showed evidence of anomalies in the drainage network. 


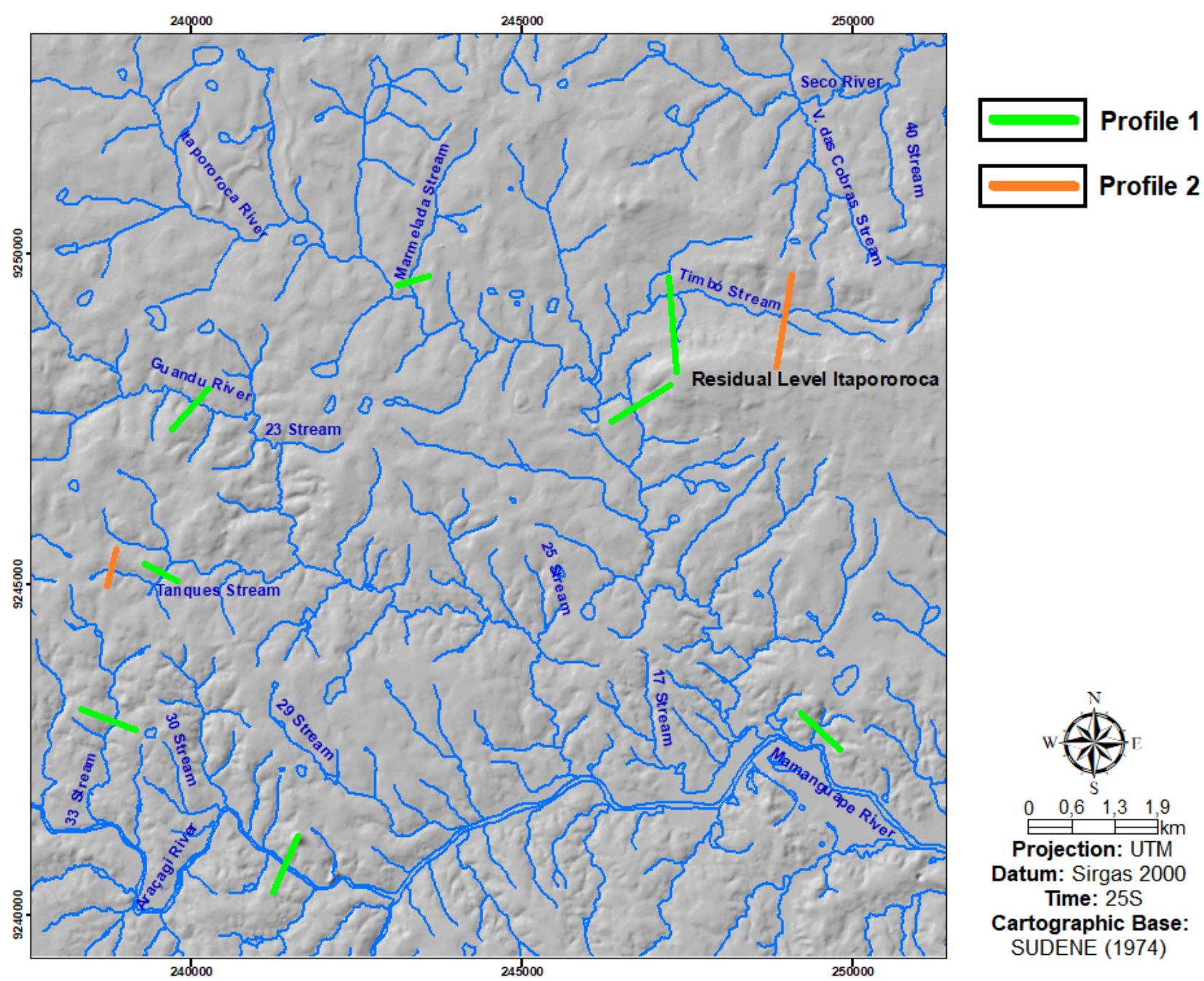

Figure 8. Selected channels with plotted profiles for the calculation of the Valley Floor Width-Valley Height Ratio (Vf).

Table 2. Morphometric variables and values obtained with the application of the $\mathrm{Vf}$ ratio in the watershed studied.

\begin{tabular}{lccccc}
\hline \multicolumn{1}{c}{ Watersheds } & $\begin{array}{c}\text { Valley bottom } \\
\text { width (m) }\end{array}$ & $\begin{array}{c}\text { Elevation of the } \\
\text { left divisor (m) }\end{array}$ & $\begin{array}{c}\text { Elevation of the } \\
\text { right divisor (m) }\end{array}$ & $\begin{array}{c}\text { Average valley } \\
\text { floor elevation }\end{array}$ & Vf \\
\hline Marmelada Stream (1) & 63,3 & 116,8 & 115,0 & 95,3 & 3,07 \\
Timbó Stream (1) & $\mathbf{5 0 , 0}$ & $\mathbf{1 9 6 , 4}$ & $\mathbf{1 8 0 , 3}$ & $\mathbf{1 0 0 , 0}$ & $\mathbf{0 , 5 6}$ \\
Timbó Stream (2) & $\mathbf{1 3 , 0}$ & $\mathbf{1 7 7 , 0}$ & $\mathbf{1 8 0 , 3}$ & $\mathbf{1 4 2 , 7}$ & $\mathbf{0 , 3 6}$ \\
Tanques Stream (1) & 144,6 & 108,0 & 112,1 & 89,3 & 6,96 \\
Tanques Stream (2) & 47,6 & 117,5 & 113,1 & 100,0 & 3,11 \\
30 Stream (1) & $\mathbf{3 0 , 8}$ & $\mathbf{9 1 , 3}$ & $\mathbf{1 0 5 , 1}$ & $\mathbf{5 0 , 0}$ & $\mathbf{0 , 6 3}$ \\
Guandu River (1) & 38,0 & 130,3 & 129,6 & 80,3 & 0,76 \\
Itapororoca River (1) & $\mathbf{4 0 , 0}$ & $\mathbf{1 8 6 , 1}$ & $\mathbf{9 3 , 1}$ & $\mathbf{7 0 , 1}$ & $\mathbf{0 , 5 7}$ \\
Araçagi River (1) & 49,0 & 79,2 & 84,3 & 35,1 & 1,05 \\
Seco Stream (1) & 27,0 & 70,1 & 70,1 & 40,2 & 0,90 \\
\hline
\end{tabular}

Note: The values in bold represent the four channels with the most significant Vf anomalies.

Asymmetric Factor Index

The Asymmetric Factor index was applied to seven little watersheds of the Seco, Itapororoca and Mamanguape rivers. The little watershed of the streams Marmelada, Timbó, Tanques, Várzea das Cobras, stream 40, stream 29 and stream 17 were chosen to apply the index (Figure 9).
The highest AF values, considered to be high asymmetry, were recorded in the watersheds of the Tanques streams, with values of 70.49, distancing 20.49 from the standard symmetry (50); and the Várzea das Cobras stream, with values of 22.96 and a distance of -27.04 from the symmetric 
watershed (50) (Table 3). These values, added to the straight and arcuate forms visualized in the drainage channels and the data obtained through the application of other morphometric indices and

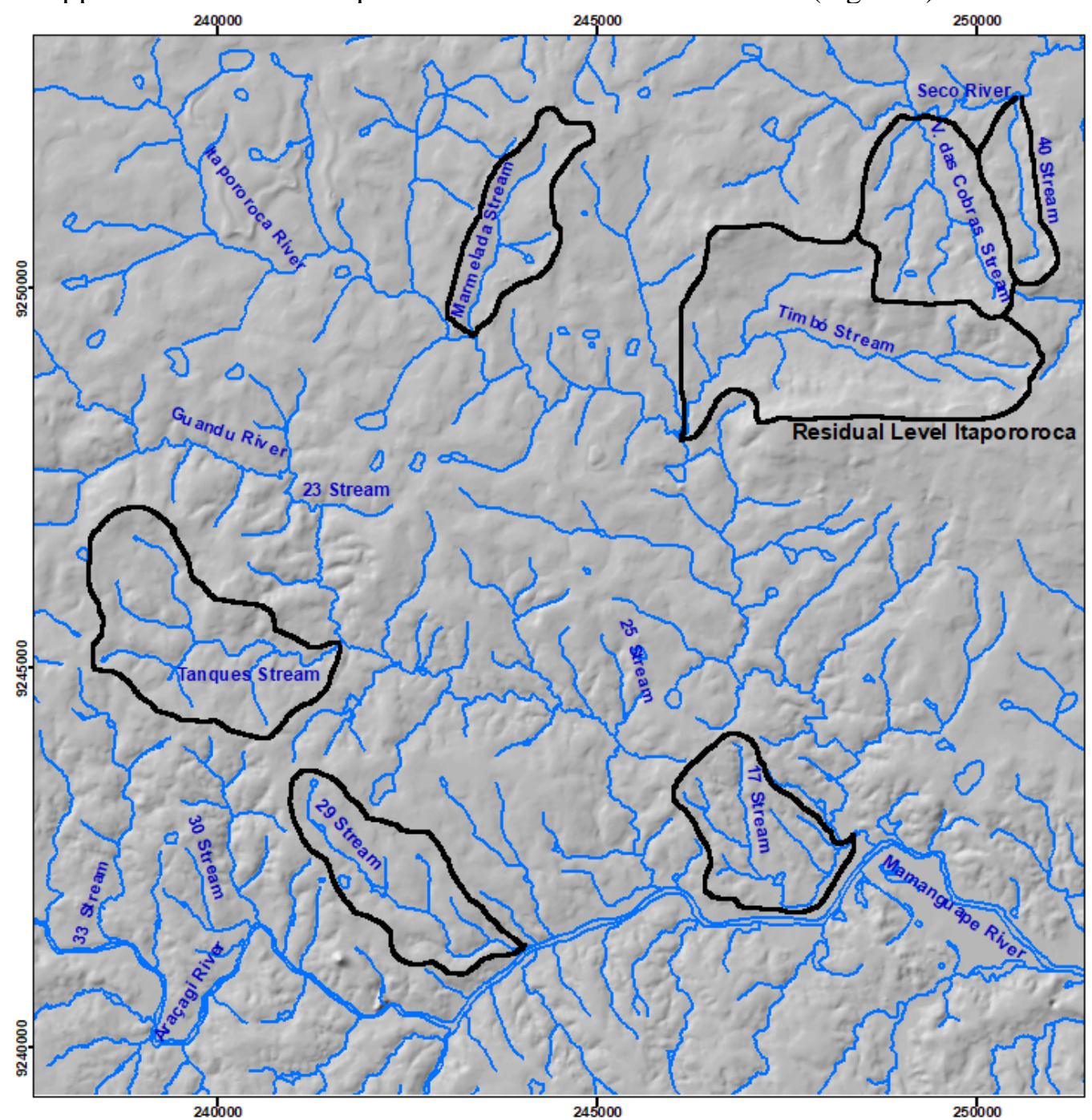

qualitative analysis, reinforce the hypothesis that the asymmetric configuration of these watersheds are the result of the performance of recent tectonic events (Figure 9).
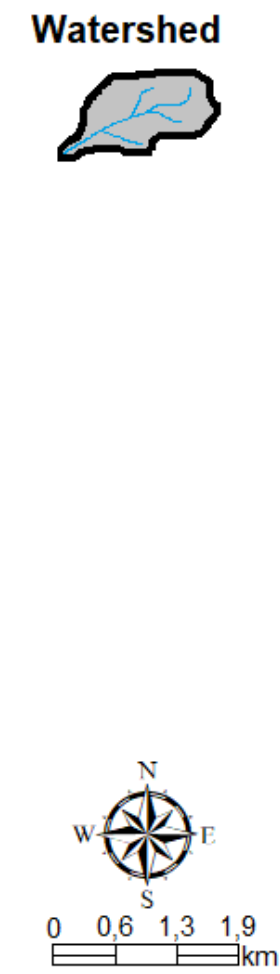

Projection: UTM

Datum: Sirgas 2000

Time: $25 \mathrm{~S}$

Cartographic Base: SUDENE (1974)

Figure 9. Watersheds selected to apply the AF index.

Looking at figure 9, there is a marked asymmetry of the drainage network with three tributaries on its right margin and no tributary on its left margin, attesting to a considerable tipping.
The AF values obtained are also compatible with the values obtained by El Hamdouni et al. (2008) in southern Spain, a region considered tectonically active.

Table 3. Values obtained with the application of the AF index in the studied.

\begin{tabular}{lccccc}
\hline \multicolumn{1}{c}{ Watersheds } & $\begin{array}{c}\text { Right area of the } \\
\text { watershed }\left(\mathbf{k m}^{2}\right)\end{array}$ & $\begin{array}{c}\text { Total area of the } \\
\text { watershed }\left(\mathbf{k m}^{2}\right)\end{array}$ & $\mathbf{A F}$ & $\mathbf{A F - 5 0}$ & $\begin{array}{c}\text { Anomaly intensity } \\
\text { class } \mathbf{A F}\end{array}$ \\
\hline Marmelada Stream & $\mathbf{1 , 1 2}$ & $\mathbf{2 , 6 1}$ & $\mathbf{4 2 , 9 1}$ & $-\mathbf{7 , 0 9}$ & Medium \\
Timbó Stream & 4,88 & 9,06 & 53,86 & 3,86 & Low \\
Tanques Stream & $\mathbf{4 , 4 2}$ & $\mathbf{6 , 2 7}$ & $\mathbf{7 0 , 4 9}$ & $\mathbf{2 0 , 4 9}$ & High \\
V. das Cobras Stream & $\mathbf{0 , 9 3}$ & $\mathbf{4 , 0 5}$ & $\mathbf{2 2 , 9 6}$ & $\mathbf{- 2 7 , 0 4}$ & High \\
40 Stream & 0,83 & 1,89 & 43,91 & $-6,09$ & Low \\
29 Stream & $\mathbf{1 , 4 6}$ & $\mathbf{3 , 7 9}$ & $\mathbf{3 8 , 5 2}$ & $-\mathbf{1 1 , 4 8}$ & Medium \\
17 Stream & 1,68 & 3,10 & 54,19 & 4,19 & Low \\
\hline
\end{tabular}

Note: The values in bold represent the four watersheds with the most significant AF anomalies. 


\section{Final considerations}

From the results obtained, it was found that the analyzes performed responded satisfactorily to the expectations raised in the introduction of this work. It was found, from the thorough analysis of the hypsometric, slope and DEM charts, that the regions with the greatest evidence of tectonic action on the Araçaji chart 1:25,000 are located in the Northeast sector, due to the influence of the Itapororoca Volcanic Unit; in the Southwest sector, in the valleys of the Guandu and Araçaji rivers, and in the lower course of the Itapororoca River, in the Southeast sector.

In the qualitative analysis of the patterns and drainage network, it was observed that the drainage patterns of the study area were configured by morphostructural influence. The first refers to the different lithologies in the area that determine fluvial processes of different intensities. The second element refers to the configuration of the relief itself, which is conditioned by lithology and, probably, also linked to the tectonism originated due to the constant separation between South America and the African continent.

This constant spacing causes an adjustment of the crust of the entire area that is attested by the intra-plate earthquakes that occurred in Brazil, mainly on the Atlantic margin. Unfortunately, the correlation between these earthquakes and the configuration of the relief still needs further

\section{References}

Andrades Filho, C.O., 2010. Análise morfoestrutural da porção central da bacia Paraíba (PB) a partir de dados MDE-SRTM e ALOS-PALSAR FBD. Tese (Doutorado). São José dos Campos, INPE.

Andrades Filho, C.O., Rossetti, D.F., 2018. Intensidade da atividade tectônica na porção emersa da Bacia Paraíba e embasamento cristalino adjacente, Nordeste do Brasil. Pesquisas em Geociências 42, 113-130.

Barbosa, B., 1995. Alostratigrafia e litostratigrafia das unidades continentais da Bacia terciária do Baixo Tejo: relações com o eustatismo e a tectónica. Tese (Doutorado). Lisboa, Universidade de Lisboa.

Barbosa, M.E.F., 2017. Tectônica e sedimentação neogénica-quaternária na planície do Rio Assu, Bacia Potiguar. Tese (Doutorado). Natal, UFRN. investigation and, therefore, this relationship was not addressed in this article.

Regarding the results obtained with the application of the morphometric indices, it can be seen that they were satisfactory, but more applications are needed in other regions of the Atlantic border in order to compare the obtained data. It is worth noting that such indices need adjustments to be applied in regions of passive continental margin, such as the Brazilian eastern border, since they were thought to be applied in areas of active continental margin. However, the fact that the area has presented results of SL, Vf and $\mathrm{AF}$ compatible with the performance of recent tectonics, justifies the consideration of these datain the present work.

The results achieved in this work, have as main objective the dissemination of this methodology to other regions of passive continental margin that can open new fields of application and understanding as to the development and evolution of the relief and its relationship with tectonics in areas of continental margin passive. There is no way to refute that the drainage network arrangements and the distinctive morphological and hydrographic features verified in a relatively small area are linked to conspicuous tectonics that cannot be disowned. The performance of the resistance and the lithological arrangement, linked to the characteristics of tectonic adjustment should be used in studies of geomorphological nature in watersheds located in the vicinity of the Atlantic continental margin.

Bezerra, F.H.R., 1998. Neotectonics in northeastern Brazil. Tese (Doutorado). London, University of London.

Bezerra, F.H.R., Amaro, V.E., Vita-Finze, C., Saadi, A., 2001. Pliocene-Quaternary fault control of sedimentation and coastal plain morphology in NE Brazil. Journal of South American Earth Sciences, 14, 61-75. doi: 10.1016/S0895-9811(01)00009-8

Brasil. Ministério da Agricultura, Pecuária e Abastecimento. Empresa Brasileira de Pesquisa Agropecuária, 2006. Sistema brasileiro de classificação de solos. Rio de Janeiro: EMBRAPA-SPI.

Brito Neves, B.B., Mantovani, M.S.M., Moraes, C.F., Sigolo, J.B., 2008. As anomalias geológicas e geofísicas da área norte de Itapororoca-PB, Folha Guarabira. Revista Brasileira de Geociências, 38, 1-23.

Bull, W.B., McFadden, L.D., 1977. Tectonic geomorphology north and south of the Garlock fault, California. In: VIII Geomorphology 
symposium - Geomorphology in arid regions (115-138), Binghamton.

Costa, L.R.F., Maia, R.P., Barreto, L.L., Claudino Sales, V., 2020. Geomorfologia do Nordeste Setentrional Brasileiro: uma proposta de classificação. Revista Brasileira de Geomorfologia 21, 185-208.

Costa, J.B.S., Bemerguy, R.L., Hasui, Y., Borges, M.S., Ferreira Júnior, C., Bezerra, P.E.L., Costa, M.L., Fernandes, J.M.G., 1996. Neotectônica da região amazônica: aspectos tectônicos, geomorfológicos e deposicionais. Genomos 4, 23-44. doi: 10.18285/geonomos.v4i2.199

Dias, R.P., 2001. Neotectónica da região do Algarve. Tese (Doutorado). Lisboa, Universidade de Lisboa.

El Hamdouni, R., Irigaray, C., Fernández, T., Chacón, J., Keller, E.A, 2008. Assessment of relative active tectonics, southwest border of the Sierra Nevada (Southern Spain). Geomorphology 96, 150-173. doi: 10.1016/j.geomorph.2007.08.004

Etchebehere, M.L.C., Saad, A.R., Fulfaro, V.J., Perinotto, J.A.J., 2004. Aplicação do Índice Relação Declividade-Extensão-RDE na bacia do Rio do Peixe (SP) para detecção de deformações neotectônicas. Geologia USP Série Científica 4, 43-56. doi: 10.5327/S1519874X2004000200004

Etchebehere, M.L.C., Saad, A.R., Santoni, G.C., Casado, F.C., Fulfaro, V. J., 2006. Deteç̧ão de prováveis deformações neotectônicas no vale do Rio do Peixe, região ocidental paulista mediante aplicação de índices RDE (Relação Declividade-Extensão) em segmentos de drenagem. Revista Geociências 25, 271-289.

Figueiredo, P.M., Rockwell, T.K., Cabral, J, Ponte Lira, C., 2019. Morphotectonics in a low tectonic rate area: Analysis of the southem Portuguese Atlantic coastal region. Geomorphology 326, 132-151. doi: 10.1016/j.geomorph.2018.02.019

Florenzano, T.G., 2008. Introdução a geomorfologia. In: T. G. Florenzano (Org), Geomorfologia: conceitos e tecnologias atuais, 11-30. São Paulo: Oficina de Textos.

Font, M., Amorese, D., Lagarde, J.L., 2010. DEM and GIS analysis of the stream gradient index to evaluate effects of tectonics: The Normandy intraplate area (NW France). Geomorphology 119, 172-180. doi: 10.1016/j.geomorph.2010.03.017

Furrier, M., 2007. Caracterização geomorfológica e do meio físico da folha João Pessoa 1:100.000. Tese (Doutorado). São Paulo, USP.
Furrier, M., Araújo, M.E., Meneses, L.F., 2006. Geomorfologia e tectônica da Formação Barreiras no estado da Paraíba. Geologia USP Série Científica 6, 61-70. doi: 10.5327/S1519874X2006000300008

Furrier, M., Vargas, G., 2018. Geomorfologia estrutural, morfotectônica e morfometria da folha Cartagena 1:100.000 - Colômbia. Colombia. Cuadernos de Geografía: Revista Colombiana de Geografía, 27, 67-86. doi: 10.15446/rcdg.v27n1.54929

Hack, J.T. 1973. Stream-profile analysis and stream-gradient index. Journal Research U.S. Geol. Survey 1, 421-429.

Hartwing, M.E., Riccomini, C., 2010. Análise morfotectônica da região da Serra dos Órgãos, Sudeste do Brasil. Revista Brasileira de Geomorfologia 11, 11-20. doi: 10.20502/rbg.v11i1.137

Hiruma, S.T., Riccomini, C., Modenesi-Gauttieri, M. C., 2001. Neotectônica no planalto de Campos do Jordão, SP. Revista Brasileira de Geociências 31, 375-384. doi: 10.25249/03757536.2001313375384

Howard, A.D., 1967. Drainage analysis in geologic interpretation: a summation. American Association of Petroleum Geologie Bulletim 51, 2246-2259.

Ivanov, M.A., Yermolaev, O.P., 2018. Capability of applying morphometric parameters of relief in river basins for geomorphological zoning of a territory. Earth and Environmental Science 107. doi: $10.1088 / 1755-1315 / 107 / 1 / 012009$

Jordan, G., 2003. Morphometric analysis and tectonic interpretation of digital terrain data: a case study. Earth Surface Processes and Landforms 28, 807-822. doi: 10.1002/esp.469

Kaur, M., Singh, S., Verma, V. K., Pateriya, B., 2014. Quantitative geomorphological analysis $\&$ land use/land cover change detection of two sub-watersheds in ne region of Punjab, India. In: The International Archives of the photogrammetry, Remote Sensing and Spatial Information Sciences Volume XL-8.

Kulkarni, M.D., 2015. The basic concept to study morphometric Analy sis of river drainage basin: a review. International Journal of Science and Research 4, 2277-2281. doi: www.ijsr.net/archive/v4i7/24071501.pdf

Leite, L. W., 1973. Geomorfologia dos tabuleiros costeiros de Sergipe. In: XXVII Congresso Brasileiro de Geologia, 373-384, Aracaju.

Leopold, L.B., Maddock, J.R.T., 1953. The hydraulic geometry of stream channels and some physiographic implications. Geological Survey Professional Paper 252, 1-56. 
Lima, C.C.U.O., 2000. Neotectonismo na costa do Sudeste e do Nordeste Brasileiro. Revista de Ciência e Tecnologia 15, 91-102.

Mahmood, S.A., Gloaguen, R., 2016. Appraisal of active tectonics in Hindu Kush: insights from DEM derived geomorphic indices and drainages analysis. Geoscience Frontiers 3, 407-428. doi: 10.1016/j.gsf.2011.12.002

Maia, R.P., Bezerra, F.H.R, 2020. Structural geomorphology in Northeastern Brazil. Springer.

Maia, R.P., Bezerra, F.H.R., 2014. Inversão neotectônica do relevo na Bacia Potiguar, Nordeste do Brasil. Revista Brasileira de Geomorfologia 15, 61-74. doi: 10.20502/rbg.v15i1.419

Mantovani, M.S.M., Shukowsky, W., Brito Neves, B.B., Rugenski, A., 2008. Gravimetric study of a potential mineral deposit in the Itapororoca region, Brazil. Geophysical Prospecting 56, 751-760. doi: 10.1111/j.13652478.2008.00696.x

Marques, J. S., 2012. Ciência geomorfológica. In: A. J. T. Guerra \& S. B. Cunha (Eds.), Geomorfologia: uma atualização de bases conceitos, 23-50. Rio de Janeiro: Bertrand Brasil.

Martinez, M., 2005. Aplicação de parâmetros morfométricos de drenagem na bacia do Rio Pirapó: o perfil longitudinal. Dissertação (Mestrado). Maringá, Universidade Estadual de Maringá.

Martins, A.A., 1999. Caracterização morfotectônica e morfossedimentar da Bacia do Baixo Tejo (Pliocénico e Quaternário). Tese de (Doutorado). Évora, Universidade de Évora.

Martins, A.A., Cunha, P.P., Huot, S., Murray, A., Buylaert, J.P., 2009. Geomorphological correlation of the tectonically displaced Tejo River terraces (Gavião-Chamusca area, central Portugal) supported by luminescence dating. Quaternary International 199, 75-91. doi: 10.1016/j.quaint.2009.01.009.

Martins, A.A., Cabral, J., Cunha, P.P., Stokes, M., Borges, J., Caldeira, B., Martins, A. C., 2017. Tectonic and lithological controls on fluvial landscape development in central-eastem Portugal: Insights from long profile tributary stream analyses. Geomorphology 276, 144 163. doi: 10.1016/j.geomorph.2016.10.012

Medeiros, V.C., 2004. Evolução geodinâmica e condicionamento estrutural dos Terrenos Piancó-Alto Brigída e Alto Pajeú, Domínio da Zona Transversal, NE do Brasil. Tese (Doutorado). Natal, UFRN.

Passarella, S., Ladeira, F.S.B., Liesenberg, V., 2016. Morfometria da bacia do rio São João,
MG: uma proposta de entendimento dos limites e da dinâmica das superfícies erosivas. Revista Brasileira de Geomorfologia 17, 241-252. doi: 10.20502/rbg.v17i2.790

Penteado, M.M., 1974. Fundamentos de Geomorfologia. Rio de Janeiro: FIBGE.

Peulvast, J.P., Claudino Sales, V., 2002. Aplainamento e geodinâmica: revisitando um problema clássico em geomorfologia. Mercator 1, 113-150. doi: 10.4215/rm.v1i1.199

Ponte, F.C., 1969. Estudo morfo-estrutural da Bacia Sergipe-Alagoas. Boletim Técnico da PETROBRÁS 12, 439-474.

Rincón, P.J., Vegas, R., 2000. Aplicación de índices geomorfológicos de actividad tectónica reciente en el antepaís Bético. Geogaceta 27, 139-142.

Rodrigues, C., Adami, S., 2009. Técnicas fundamentais para o estudo de bacias hidrográficas. In: L. A. B. Venturi (Org.), Praticando Geografia: técnicas de campo e laboratório, 131-166. São Paulo: Oficina de textos.

Saadi, A., 1993. Neotectônica da Plataforma Brasileira: esboço e interpretação preliminares. Geonomos 1, 1-15.

Santos, E.J., Ferreira, C.A., Silva Júnior, J.M., 2002. Geologia e recursos minerais do estado da Paraíba. Recife: Ministério das Minas e Energia/CPRM. 2 mapas. Escala 1:500.000.

Sebber, L., Gornitz, V., 1983. River profiles along the Himalayan arc as indicators of active tectonics. Tectonophysics 92, 335-367. doi: 10.1016/0040-1951(83)90201-9

Silva, P.G., Goy, J.L., Zazo, C., Azcárate, T.B., 2003. Fault-generated mountain fronts in southeast Spain: geomorphologic assessment of tectonic and seismic activity. Geomorphology $50, \quad 203-225$. doi: $10.1016 /$ S0169$555 \mathrm{X}(02) 00215-5$

Silva, I.C., 2020. Geomorfologia, morfoestrutura e morfotectônica do nordeste do Estado da Paraíba. Tese (doutorado). João Pessoa, UFPB.

Souza, L.S.B., Rossetti, D.F., 2011 . Caracterização da rede de drenagem na porção leste da ilha do Marajó e implicações tectônicas. Revista Brasileira de Geomorfologia 12, 69-83. doi: 10.20502/rbg.v 12i1.220

Strahler, A.N., 1952. Hypsometric (area-altitude) analysis of erosional topography. Geological Society of America Bulletin 63, 1117-1142.

Sudene - Superintendência de Desenvolvimento do Nordeste., 1974. Carta topográfica Araçaji (Folha SB.25-Y-A-V-3-NE). Recife: Sudene. Escala 1:25.000.

Teixeira, J.A.A., 2006. Geomorfologia e morfotectônica de relevos quartzíticos: 
Revista Brasileira de Geografia Física v.13, n.04 (2020) 1570-1586.

implicações na gestão de georrecursos. Dissertação (Mestrado). Aveiro, Universidade de Aveiro.

Volkov, N.G., Sokolovsky, I.L., Subbotin, A.I.,
1967. Effect of recent crustal movements on the shape of longitudinal profiles and water levels in rivers. In: International Symposium on River Mechanics, 105-116, Bern. 